\title{
New altitudinal records of the endemic species Cycloramphus brasiliensis (Anura, Cycloramphidae) from the Atlantic Rainforest in the state of Rio de Janeiro, southeastern Brazil
}

\author{
Maia-Carneiro, T. *, Dorigo, TA., Almeida-Gomes, M., van Sluys, M. and Rocha, CFD. \\ Departamento de Ecologia, Universidade do Estado do Rio de Janeiro - UERJ, \\ Rua São Francisco Xavier, 524, CEP 20550-019, Rio de Janeiro, RJ, Brazil \\ *e-mail: thiagomaianc@gmail.com
}

Received June 22, 2011 - Accepted July 6, 2011 - Distributed February 29, 2012

(With 1 figure)

The genus Cycloramphus Tschudi, 1838 is presently composed of 27 anuran species distributed throughout the Atlantic Forest of southeastern Brazil (Frost, 2011). Heyer (1983), in a study dealing with variation and systematic of frogs of the genus Cycloramphus, removed C. brasiliensis (Steindachner, 1864) (Cycloramphidae) from the synonymy of C. fuliginosus Tschudi, 1838 (Cycloramphidae); that is the only available study on the former species. Cycloramphus brasiliensis (Figure 1) is endemic to the relatively small portion of the Atlantic Forest of Serra dos Órgãos and Serra da Mantiqueira, in the state of Rio de Janeiro. This species has rheophilic habits, being associated with fast-moving rocky portions of clear freshwater rivers in Atlantic Forest remnants. Cycloramphus brasiliensis is considered near threatened; however, it is almost qualified as vulnerable due to a trend of decreasing populations (IUCN, 2010). Existing knowledge on C. brasiliensis distribution reports that populations of the species live at altitudes ranging from 800-1200 m elevation (Frost, 2011). Herein we provide additional information regarding the altitudinal range of distribution of this species to lower elevations, near sea level.

The individuals of Cycloramphus brasiliensis were sampled in September and October, 2004 and between

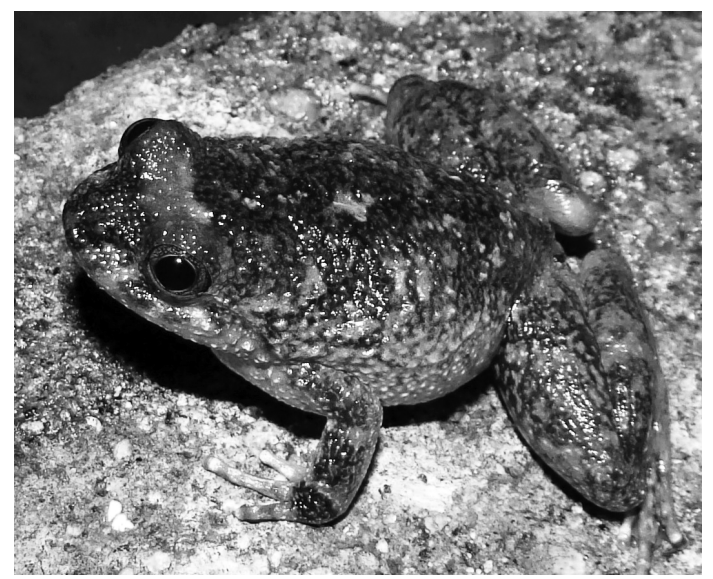

Figure 1. The rheophilic species Cycloramphus brasiliensis (Photo by M. Almeida-Gomes).
July 2007 and March 2010 using Visual Encounter Surveys (Crump and Scott, 1994) performed by transects, in two localities of Atlantic Forest in the state of Rio de Janeiro, southeastern Brazil: the Estação Ecológica Estadual Paraíso (22 $29^{\prime} \mathrm{S}$ and $42^{\circ} 55^{\prime} \mathrm{W}$; elevation $150-290 \mathrm{~m}$ ) and the Reserva Ecológica de Guapiaçu ( $22^{\circ} 24^{\prime} \mathrm{S}$ and $42^{\circ} 44^{\prime} \mathrm{W}$; elevation 40-400 $\mathrm{m}$ ). These forested areas are approximately $9 \mathrm{~km}$ apart, and are made up of continuous forests, having different levels of regeneration and are composed predominantly of low montane and sub-montane tropical forest vegetation. The climate in the region is wet and warm, and annual rainfall varies from 2000 to $2500 \mathrm{~mm}$. Mean annual temperature is about $24^{\circ} \mathrm{C}$ (Rocha et al., 2007).

We found individuals of Cycloramphus brasiliensis at the two localities sampled in this study. Frogs we sampled were found at minimum altitudes of $150 \mathrm{~m}$ elevation in lowland areas in the Atlantic Forest, which indicates that the species occurs at least about $650 \mathrm{~m}$ below the previously suggested altitudinal range of the species distribution (the species was considered restricted to elevations ranging from 800-1200 m above sea level Frost, 2011). Therefore, this endemic species may occur at altitudes ranging from 150-1200 $\mathrm{m}$ above sea level in the Atlantic Forest biome.

Acknowledgements - We thank Nicholas J. Locke of the Reserva Ecológica de Guapiaçu and Alcides Pissinatti of the Estação Ecológica Estadual Paraíso, especially for logistical support and for their permission to work in the areas. We also thank many colleagues for field assistantship in different moments throughout the study. This study was supported by research grants from the Conselho Nacional de Desenvolvimento Científico e Tecnológico - CNPq to C.F.D. Rocha (processes 304791/2010-5 and 470265/2010-8). C.F.D.Rocha also received a grant from the Fundação de Amparo à Pesquisa do Estado do Rio de Janeiro - FAPERJ through the "Programa Cientistas do Nosso Estado" (process E-26/102.404.2009). T. Maia received an MSc grant from the Coordenação de Aperfeiçoamento de Pessoal de Nível Superior - CAPES. TA. Dorigo received an MSc grant from FAPERJ and MA.Gomes received a graduate fellowship from Conservation International do Brasil and FAPERJ. We also thank D. Vrcibradic for his aid and helpful suggestions. 


\section{References}

CRUMP, ML. and SCOTT-JUNIOR, NJ., 1994. Visual encounter surveys. In HEYER, WR., DONNELLEY, MA., McDIARMID, RW., HAYEK, LC. and FOSTER, MS., (eds.). Measuring and Monitoring Biological Diversity: Standard Methods for Amphibians. Washington: Smithsonian Institution Press. p. 84-92.

FROST, DR., 2011. Amphibian Species of the World: an Online Reference. version 5.5. New York: American Museum of Natural History. Available from: <http://research.amnh.org/vz/herpetology/ amphibia/>. Access in: 16 nov. 2011.

HEYER, WR. 1983. Variation and systematics of frogs of the genus Cycloramphus (Amphibia, Leptodactylidae). Arquivos de Zoologia, vol. 30, p. 235-339.
International Union for Conservation of Nature - IUCN, 2010. IUCN Red List of Threatened Species. Version 2010.4. <www. iucnredlist.org>. Downloaded on 05 June 2011.

ROCHA, CFD., VRCIBRADIC, D., KIEFER, MC., ALMEIDAGOMES, M., BORGES-JÚNIOR, VNT., CARNEIRO, PCF., MARRA, RV., ALMEIDA-SANTOS, P., SIQUEIRA, CC.; GOYANNES-ARAÚJO, P., FERNANDES, CGA., RUBIÃO, ECN. and Van SLUYS, M., 2007. A survey of the leaf-litter frog assembly from an Atlantic forest area (Reserva Ecológica de Guapiaçu) in Rio de Janeiro State, Brazil, with an estimate of frog densities. Tropical Zoology, vol. 20, p. 99-108. 